\title{
面内㨝りを受ける円形張力膜のしわ
}

一ポリエステルフィルムと $\mathrm{C}$ 種膜の実験一

\author{
WRINKLING ON STRETCHED CIRCULAR MEMBRANES UNDER \\ INPLANE TORSION \\ -Experiments with polyester films and coated fabrics-
}

宮村 倫 司*, 半谷裕彦**

Tomoshi MIYAMURA and Yasuhiko HANGAI

\begin{abstract}
The problem of circular stretched membranes under inplane torsion is a typical example in studying wrinkling on membrane structures. In this paper experiments of the example are carried out. A feature of the experiment is that both isotropic polyester films and orthotropic coated fabrics are treated, since membranes used in spatial architectures are usually orthotropic. Few studies on wrinkling on orthotropic membranes can be found. Another feature of the experiment is that stresses in the wrinkled membranes are measured. For that purpose, first a method for measuring stresses in thin membranes is presented. Second stresses in the wrinkled circular membranes are measured by using the method, and finally principal stresses are obtained. The results show that (1)there are no compressive stresses in the wrinkled membranes, (2)directions of tensile principal stresses almost coincide with directions of wrinkles, and (3)in the coated fabrics, these two kinds of directions almost coincide with directions of fabrics. Photos of wrinkles on various kinds of membranes are also shown.
\end{abstract}

Keywords : $\quad$ wrinkling, circular stretched membrane, torsion, orthotropic membrane ,experiment, measurement of stresses

しわ、円形張力膜、㨝り、直交異方性、実験、忘力測定

1 はじめに

しわの問題は膜構造を考える上で本質的な問題であり、これま でにも多くの研究が行われてきた。2節に示寸面内据りを受ける 円形張力膜の問題は、しわの研究における標準的な例題であると いえる。本論文ではこの例題に関して著者等がこれまでに行って きた実験の結果をまとめて報告する。

円形張力膜の面内据りの既往の実験例としてMikulas(1964) 4) によるものがある。実験に用いられた膜は等方性のポりエステル フィルムである。ここでは初期張力の精密な導入法、微小な回転角 の精密な測定法等が示されている。各種の初期張力に対する㨭り モーメントー回転角曲線は、Stein 等 (1961) 3 )の理論に基づく解と 非常に良く一致している。Hamada等 (1986) ${ }^{10)}$ は各種の境界条件 に対して差分法により座屈解析を行い、同時に行った実験結果と 比較している。ただし、実験、解析共に鋼板に対するものであり、 初期張力は導入されていない。

この他にもDean(1924) ${ }^{1)}$ が座屈解析との比較のために、また Stein 等 3 ) 部分的な領域の張力場の理論解との比較のためにそ れぞれ実験を行ったが、どちらも写真が示されているのみである。 円形膜の㨝り以外の例題についてもいくつかの実験例がある。 川口 (1977) ${ }^{9)}$ は偏平な回転曲面に内圧をかけた時に生じるしわの
実験を行った。Mansfield $(1970)^{5)}$ は自由境界を持つ矩形膜にせん 断力を与えた場合について張力場理論による解析例とともに実物 の写真を示している。Moriya 等 (1971) は円形の穴を有寸る矩形板 のせん断座屈の実験を行った。菊池 (1974) ${ }^{7)}$ は矩形フィルムの単 純せん断について実験を行い、歪ゲージによる測定の結果から応 力を求めた。ただし、歪グージの剛性を考慮していないため、得 られた応力は実際よりも小さいようにみえる。菊池は正方形開口 を持つ場合についても実験を行った ${ }^{8)}$ 。Roddeman 等 (1987) ${ }^{12)}$ は 彼らが提案したしわの解析法 ${ }^{11)}$ の検証のために、引き伸ばした 矩形膜をせん断変形させる実験を行った。結果は良く一致してい る。塚越等 (1995) ${ }^{14)}$ はいろいろなパターンのスリットを持つ鋼板 耐震壁の挙動を調べるために、切れ目を入れた薄膜のしわの実験 を行った。

以上に示した膜のしわに関する実験的な研究では、建築の膜樓 造で一般的な直交異方性膜に関するものはないようである。そこ で、本論文では等方性および直交異方性の膜を対象とした、内形 張力膜の据りの実験について報告する。本実験のもうひとつの特 徵はしわ発生時の応力の測定を試みたことである。しわの発生機 構は膜の忘力場と密接な関係があるから、応力の測定は有意義で あるといえる。态力測定は Mikulas 4 )の赛験においても行われて 
おらず、その他の測定例もあまりない。そのため最初に薄い膜の 応力測定法を開発することが必要となった。

本実験に関してはこれまでにも報告を行ってきた15）16）21）19）。 これらの中で初期の論文 15）16）21)に示した忘力の測定結果は、 測定方法が曖昧であり精度に問題がある。本論文ではこのような 点を正し、文献 19)の結果を中心に一連の実験結果をまとめて最 終的な考察を行ったものである。文献 19)に示した結果は、後に有 限要素法による分岐解析の結果と比較し、妥当であることを確認 している21)。

\section{2 面内据りを受ける円形張力膜}

図1のように円形膜の中央に剛体の円盤を取り付けた後に、外 側境界を半径方向外向きに一様変位させて初期張力を導入する。 なお、先に初期張力を導入してから、円盤を取り付ければ等張力 となるが、ここでは扱わない。初期張力導入後に外側境界は固定 し、中央円盤を面内に回転させる。

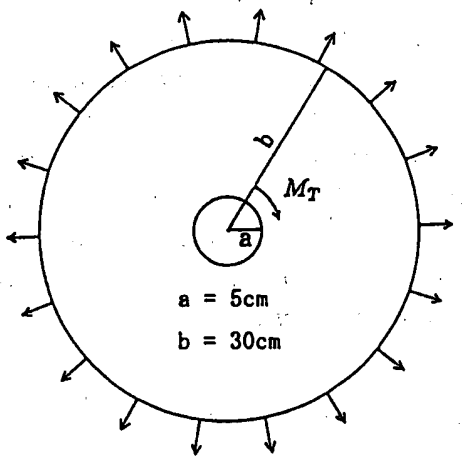

图 1:面内㨝りを受ける円形張力膜

\section{3 実験方法}

\section{1 概要}

第 1 節にも述べたように、面内挨りを受ける円形張力膜のしわ に関しては、等方性弹性体について Mikulas が精密な実験を行っ た 4)。そこでは、非常に精密な初期張力の導入法により、初期張 カの大きさやモードが据りモーメントー回転角関倸におよぼす影 響を調查している。ただし、等方性弾性体の膜のみを扱っている。 本実験ではMikulas の実験で行われていない事項に重点を置く ことにする。すなわち、本実験では直交異方性の膜も扱い、また、 しわ発生時の膜の応力を測定する。薄い膜の応力を測定した例は あまりないため、最初に歪ゲージの測定值を利用して応力を求め るための方法を提案する 18 )。

\section{2 実験に用いる膜}

実験で使用する膜材とそれらの弾性材料定数を表 1 に示す。ポ リエステルフィルム（商品名：東レのルミラー）はほぼ理想的な等 方性弾性体である。C 種膜は PVC コーティングされたポリエステ ル織維であり 13)、小規模な空間建築に用いられる。直交異方性で あり、応力-歪曲線は初期には剛性が低く、緘維のゆるみがなくなっ た時点で剛性が上がる。

ポリエステルフィルムについては一軸引張試験を行い、膜に取 り付けた変位計により測定した歪と荷重から求めた応力の関係か ら、ヤング率とポアソン比を求めた。せん断剛性係数は弾性体の 公式から計算した。
一方、瀬川等 13)によれば、C 種膜は材料非線形性が強く、その 材料定数は荷重レベルや応力比により異なる。ここでは二方向の ヤング率とポアソン比として、応力比 $1: 1$ で応力が $3.5 \mathrm{kgf} / \mathrm{cm}$ 程度 の時にクリープを除いて得られる值を文献 13)より引用した。C 種膜のせん断剛性倸数は膜構造協会試験法標準 23)に従った材料試 験により求めた。なお、これらの材料定数は解析を行なう場合に 必要となる。

表 1 : 実験に用いた膜材料

(厚さの単位 $: \mathrm{cm} 、 E_{i} t, G t$ の単位 $: \mathrm{kgf} / \mathrm{cm}$ )

\begin{tabular}{l|cccccc}
\hline \hline 材料名 & 厚さ $t$ & $E_{1} t$ & $\nu_{12}$ & $E_{2} t$ & $\nu_{21}$ & $G t$ \\
\hline ポリエステル & 0.018 & 1022 & 0.267 & - & - & 404 \\
種膜 & 0.050 & 391 & 0.0 & 194 & 0.36 & 11 \\
\hline
\end{tabular}

\section{3 試験装置}

写真 1 は試験風景であり、図2、3 はそれぞれ試験装置の平面図 と側面図である。平面図に示寸ように、8 個のチャックにより膜の 周辺部を挟んで固定し、これらのチャックを錘で引つ張ることによ り近似的に半径方向への一様な引張を表す (写真 2 参照)。チャック のスライド部にはベアリングが入っていないので摩擦が多少はあ る。膜の中央部は二枚の鉄の円盤で挟む。この円盤の中心には軸 を取り付け、ベアリングの入うた軸受けにより架台に固定する。中 心軸にはアームを取り付け、これを錘で引くことにより据りを導 入する。この錘の重さはロードセルで連続的に測定する。ロード セルの測定值にアームの長さを掛けると㨝りモーメントとなる。

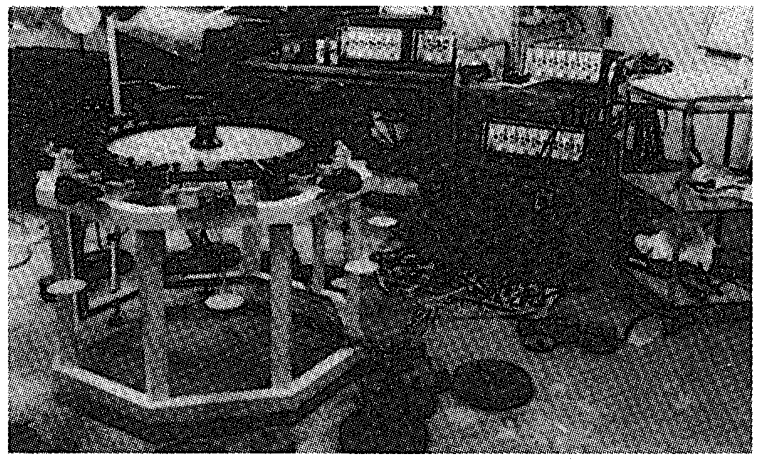

写真 1: 実䮬風暴

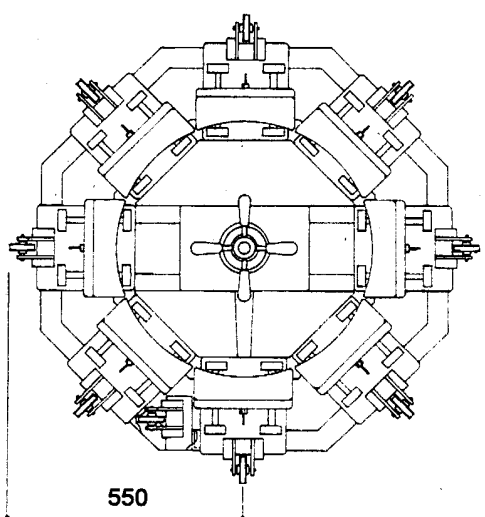

図 2: 試験機平面図

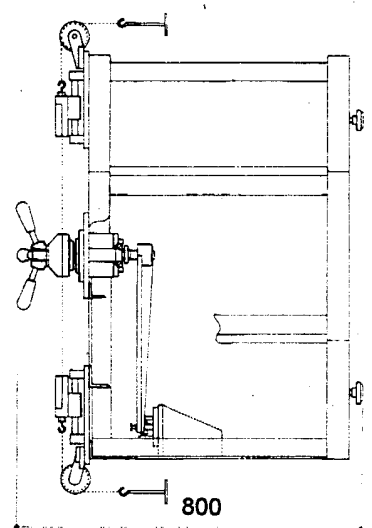

図 3: 試験機側面図（縦）
3.4 薄い膜の応力測定法 ${ }^{18) 19)}$

3.4.1 概要

膜材は一般的に非線形の材料特性を示すが、薄い膜に歪ゲージ を貼るとそこでは線形に近い材料特性となる。このため引張試験 により、歪ゲージと膜および接着剤からなる一種の複合材料の材 


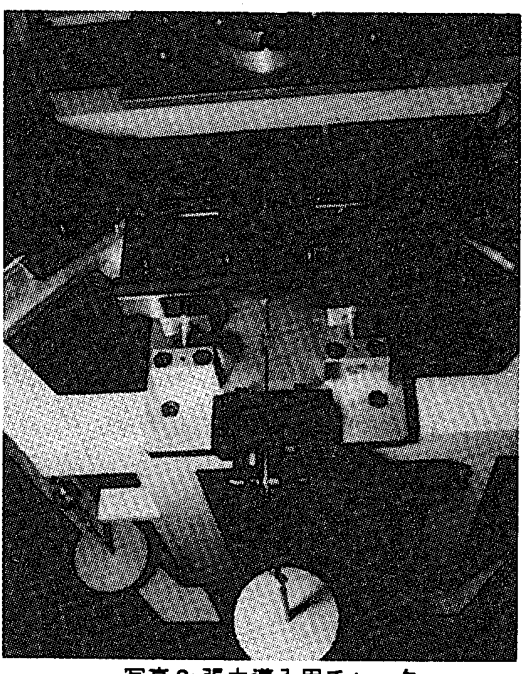

写真 2: 張力導入用チャック

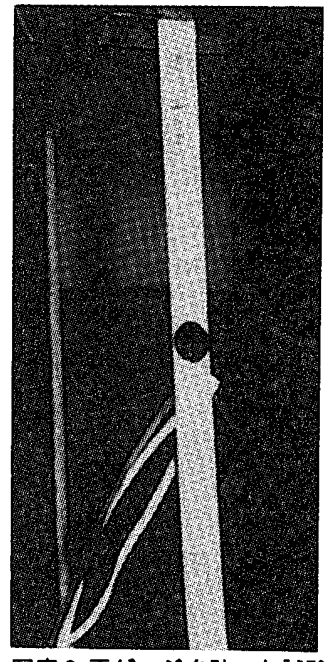

写真 3: 歪ゲージを貼った試験体

料定数を評価しておけば、歪ゲージの測定值からゲージを貼った点 の応力を計算することができる。歪ゲージを貼った点には小さな ロードセルが埋め込まれていると考えればよい。歪ゲージが貼つ てある点の忘力とその周辺の応力とは钩り合っているので、ゲー ジにかかる応力によりこの点の本来の応力を評価することができ る。ただし、ゲージを貼った部分への応力集中が多少はあるためこ れが誤差となる。なお、以下では全て平面応力を考えている。

ゲージを貼った部分の㓮性を評価するために、図 4 や写真 3 に示 寸細長い試験体を用いて引張試験を行う。しわ発生領域は一軸的 な引張応力場となることが予想されるため、このような細長い試 験体の一軸引張試験時とほぼ同様な忘力場となると考えられる。 参考までに、井合 2)はしわの方向に膜を切断しても歪エネルギー は減少しないと仮定し、しわ発生領域を細長い帯の集合であると 考えることにより張力場理論の基礎式を導いた。直交異方性の C 種膜ではゲージの貼られた部分は直交異方性の弾性体であるとみ なし、ふたつの瀻維方向およびそれに対して 45 度の方向について 引張試験を行うことにより五個（理論的には独立なものは四個） の弾性係数を求める 18)。

\subsection{2 試験体形状と用いる歪ゲージ}

図 4 は試験体の形状である。円形の二方向歪ゲージを使う。な お、しわの塞験ではこれと同寸法の三方向ゲージを用いる。二方 向ゲージと三方向ゲージの剛性は同じであるとみなす。歪ゲージ の貼ってある部分に全ての荷重をかけるために、試験体幅はゲー ジのバースの直径の $1.1 \mathrm{~cm}$ と一致させる。ゲージは各試験体とも 両面に貼り、ふたつの面の值の平均を用いる。

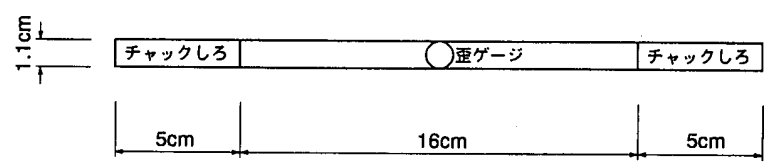

図 4: 材料試験用試験体

\subsection{3 引張試験の結果と応力測定用材料定数の評価}

ポリエステルフィルムと $\mathrm{C}$ 種膜（三方向）についてそれぞれ二回 試験を行ったところ、各々ほぼ同じ結果が得られた。図 5 にポリエ ステルフィルムの結果、図 $6 \sim 8$ に 種膜の三方向の結果を示す。合

応力は荷重を試験体幅で割ることにより求め、歪は表と裏のゲー ジの測定値の平均である。載荷方向とそれに直交する方向の歪の 測定值をまとめて示す。それぞれ弾性的举動を示している。そこ で、最小二乗法により求めた直線を破線で示す。表 2 にこれらの図 から得られた応力測定用の材料定数を示す。表 1 に示した本当の 材料定数とは全く異なっていることに注意する。なお、表 2 の值は $\nu_{12} / E_{1}=\nu_{21} / E_{2}$ を満たしていないがこのまま用いることにした。 表 $2:$ 応力測定用の材料定数 $\left(E_{i} t, G t\right.$ の単位 $\left.: \mathrm{kgf} / \mathrm{cm}\right)$

\begin{tabular}{c|ccccc}
\hline \hline 材料名 & $E_{1} t$ & $\nu_{12}$ & $E_{2} t$ & $\nu_{21}$ & $G t$ \\
\hline ポリエステルフィルム & 2668 & 0.315 & - & - & 1015 \\
C 種膜 & 3690 & 0.298 & 1908 & 0.337 & $\mathbf{5 8 8}$ \\
\hline
\end{tabular}

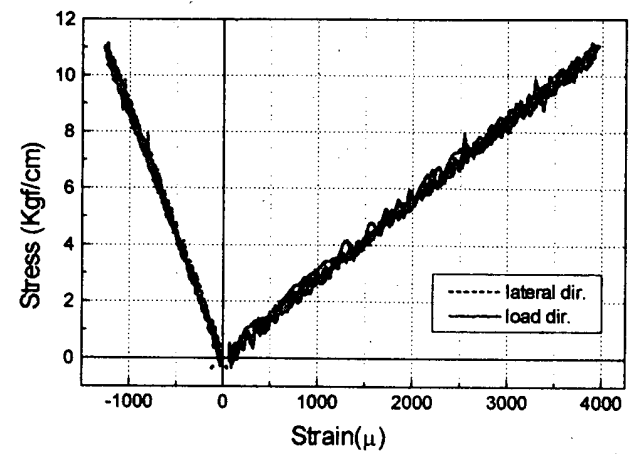

图 5 : 応カ-歪曲線（ポリエステルフィルム）

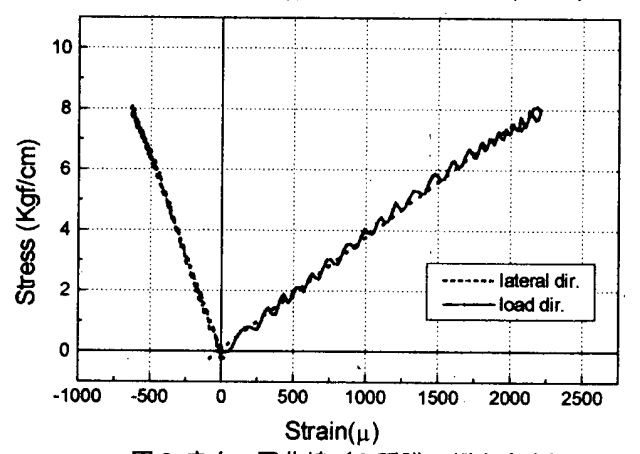

図 6: 沁力-歪曲線（C 喠膜、綎糸方向）

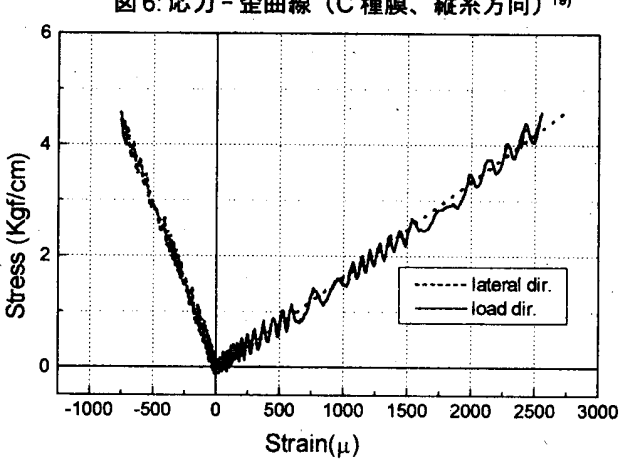

図 7:応力-柾曲線（C 理膜、横糸方向） 19

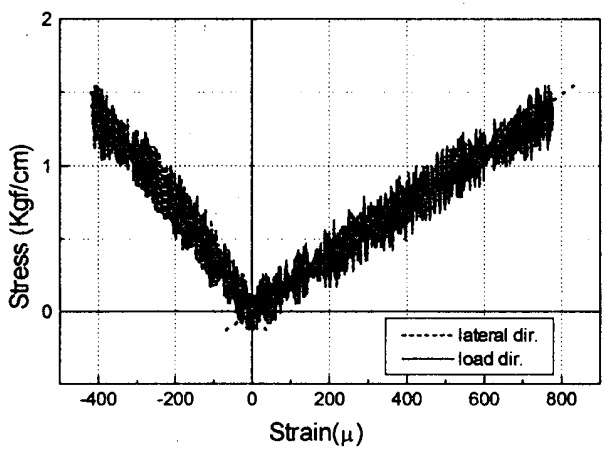

图 8: 応力-歪曲線（C 種膜、45 度方向） ${ }^{19}$ 


\subsection{4. 提案した応力測定法の简単な検証}

応力測定の最も簡単な例として、図 9 に示すような幅 $4 \mathrm{~cm} の$ 試 験体 (C 種膜、綐系方向)，の中央に歪ゲージを貼り态力を求めて みる。図 10 は幅 $4 \mathrm{~cm}$ の試験体の引張試験の結果である。この時: 荷重を試験体の幅で割ることにより歪ゲージの貼っていない断面 （例えば、図 9 の点線をつけたところ）の応力を求めることができ る。これは求めたい本当の応力であり一般の構造ではわからない。 歪ゲージの測定值に対する本当の応力は寒線でプロットする。た

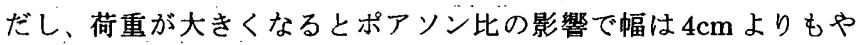
や小さくなるため、応力は図10の実線よりも少し大きくなる。一 方、歪ゲージにかかる㐫力は図 6 により評価されるから、これを 点線で重ねて描いておく。ポアソン比の影響が小さい初期段階か ら、点線で示す提案した応力測定法による応力の方がやや大きい。 つまり、ゲージを貼った部分に応力集中が少しはあることがわか る。しかし、その差は小さく、図 5 8 の応力-歪曲線から応力を推 定してもそれほど悪い結果とはならない。

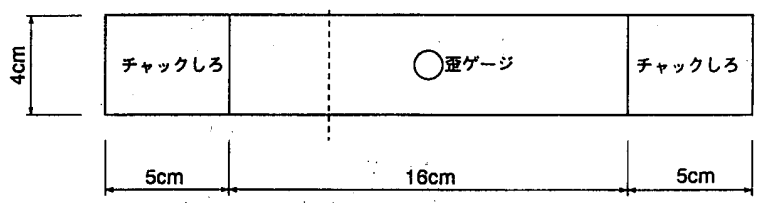

图 9 : 応力測定の検証用試倹体

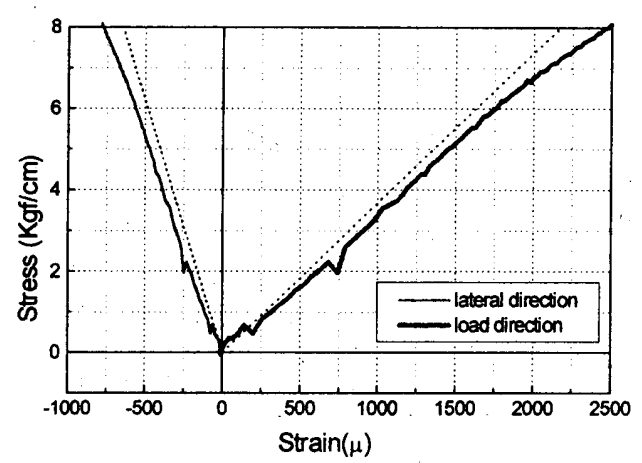

图 10: 応力測定法の検証（点線は図6より推定した応力）

\section{4 実験結果}

\section{1 円形膜試験体}

三方向円形歪ゲージを膜の両面に貼る(3.4.2 節参照)。歪ゲー ジの位置は図 11 13に示す三種類である。図 13 の A と C の゙ー ジは直交異方性の場合、織維方向と一致した中央円盤の接線上に ある。また、図11のBのグージも同様である。直交異方性の膜で はこの接線上の応力が高いという数值解析の結果を考慮している。 各ゲージの向きは図 14 に示しでおり、C 種膜の場合には織維の方 向に一致させる。表 3 に膜材とゲージ配置の組み合わせ、および、 試験体の記号を示す。

\begin{tabular}{c|c|c}
\multicolumn{3}{c}{ 表 $3:$ 試験体 } \\
\hline \hline 試験体の記号 & 膜の名称 & ゲージ配置 \\
\hline ML1 & ポリエステルフィルム & 図 11 \\
ML2 & ポリエステルフィルム & 図 12 \\
MC1 & C 種膜 & 図 11 \\
MC2 & C 種膜 & 図 13 \\
\hline
\end{tabular}

\section{2 㤂力測定}

初期張力の導入では、相对する二個のチャックの皿に同時に鍾 を載せていき、いつも亦称に荷重がかかるようにする。最初は各々

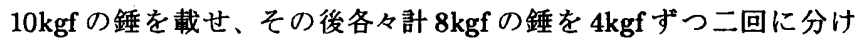

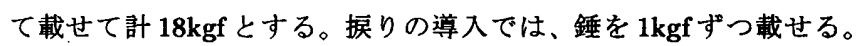
一個あたり数秒かけて載せていき、最後の錘を載せたらすぐに一 個ずつ降ろす。最後に初期張力導入用の錘を順に降乃す。

図 15、16 は据りモーメントと歪の関倸である。表 3 の試験体 ML2 とMC2 についての結果のみ示す。歪は表と裹の平均值であ り、図中の先頭に $\mathrm{c}$ の付いた番号は図 14 の表のゲージ番号に対応 している。しわの発生により曲線が折れ曲がっている。等方性の ポリエステルフィルムの場合は各曲線がほほ同時に折れ曲がるが、 $\mathrm{C}$ 種膜では変形が周方向について均質ではないため、折れ曲がる 点はダージ位置により異なる。参考のためにしわ発生が目で確認 された荷重を表 4 に示す。

$\mathrm{C}$ 種膜ではクリープ等により変形が進むため、錘の重さを一定 にしても中央円盤は時間と共に回転していく。しかし、态力は一定 の重さの錘に釣合っているのでそれ程変化しない。ところで、3.4 節に示したように歪グージの測定值は态力に比例するものであり 膜の変形を表してはいない。従って、応力を表す図 16 の歪ゲージ の測定值は錘により段階的に載荷しているにもかかわらずかなり 滑らかであり、載荷と除荷の経路もそれ程異ならない。

最後にロゼット解析によりせん断歪を求め、先の引張試験で得 た表 2 の值を用いれば応力が得られる。

表 4. しわが確認された荷重

\begin{tabular}{c|c|c}
\hline \hline 試験体の記号 & 鍾の数 & 挨りモーメメ下 \\
\hline ML1 & 4 個 & $160 \mathrm{kgf} \cdot \mathrm{cm}$ \\
ML2 & 5 個 & $200 \mathrm{kgf} \cdot \mathrm{cm}$ \\
$\mathrm{MC} 1$ & 2 個 & $80 \mathrm{kgf} \cdot \mathrm{cm}$ \\
$\mathrm{MC2}$ & 4 個 & $160 \mathrm{kgf} \cdot \mathrm{cm}$ \\
\hline
\end{tabular}

\section{3 主応力図}

図 17、18に得られた主応力図を示す。初期張力導入後（据り モーメントは0)、しわ発生直後、および、据りモーメントが最大 (400 kgf $\cdot \mathrm{cm})$ の状態における主応力である。しわ発生直後の㨭 りモーメントは、前節に示した据りモーメントー歪曲線の折れ曲 がる点と表 4 を参考にして、ポリエステルフィルム：160kgf $\cdot \mathrm{cm}$ 、 $\mathrm{C}$ 種膜 : 80 kgf $\cdot \mathrm{cm}$ とした。ML1 とML2、および、MC1 と MC2 は それぞれゲージ位置が異なるだけで同じ条件で塞験しているので、 主态力をひとつの図に重ねて描く。

ポリエステルフィルムの初期張力導入直後の結果では主応力の 方向にやや乱れがある。また、この位置では半径方向の忍力が大 きいはずだがそうでない点もある。初期張力導入の精度はそれ程 良くない。C 種膜についても同様である。ただし、後の図に示す ように、据りによる応力は初期張力に比べてかなり大きくなるの で、最終的な状態における初期張力の乱れの影響は相対的に小さ い。なお、外周のチャックのスライド部の摩擦等により、錘の重さ の約 $80 \%$ 程度が膜面に伝わっていることが、ポリエステルフィルム の測定結果と理論解の比較から分かったので、解析との比較を行 う場合にはこれを考慮する必要がある。

据り導入後の各主応力図をみると圧縮応力はほとんど発生して おらず、理想的な張力場に近い状態であるといえる。曲げ䣓性が ある程度大きいと圧縮応力の存在が許容されると考えられるが、 ここで取上げた膜の曲げ剛性程度では、圧縮态力はほとんど解放 


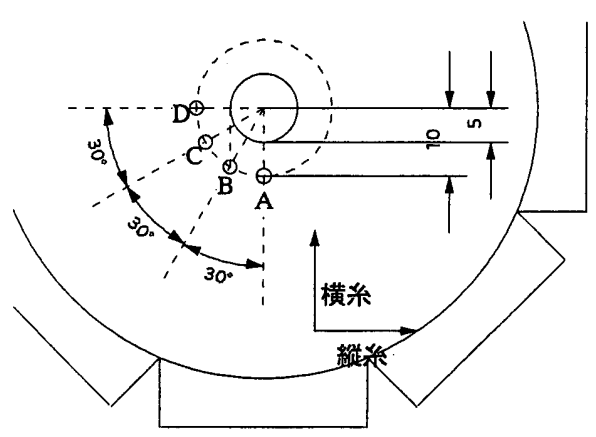

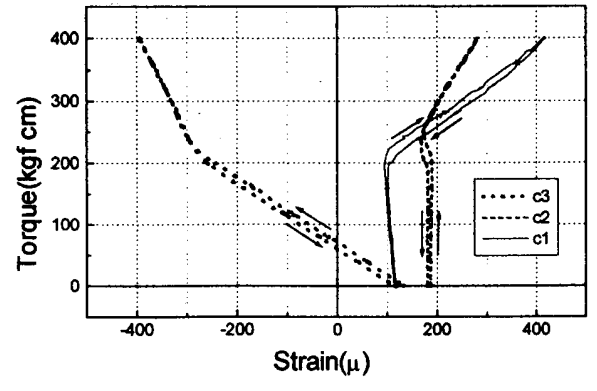

(15a)

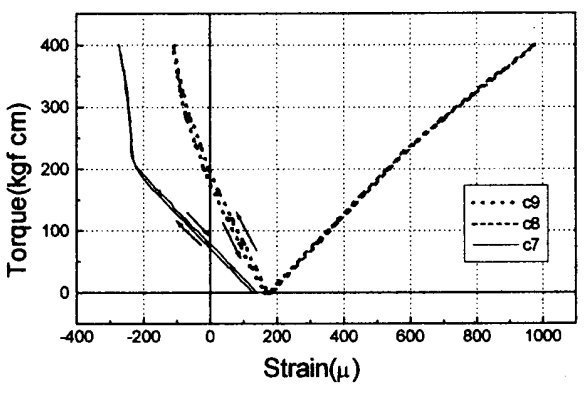

(15b)

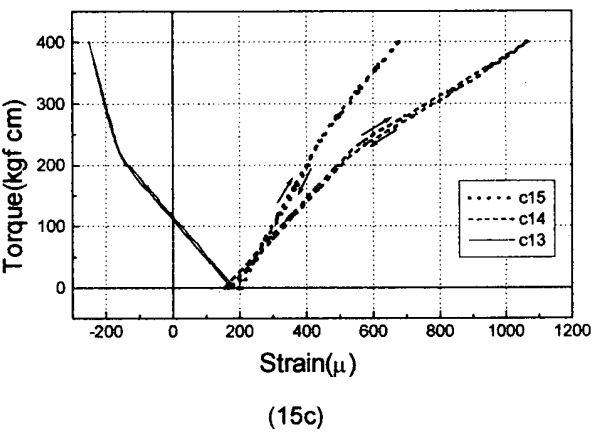

(15c)

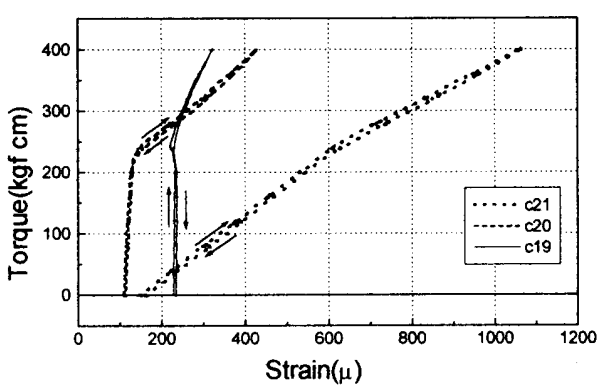

(15d)

図 15: 据りモーメントー歪曲線 19

(ML2 : ポリエステルフィルム)

各図中のc+番号は図 14 に示す表の

歪ゲージの番号に対応する。

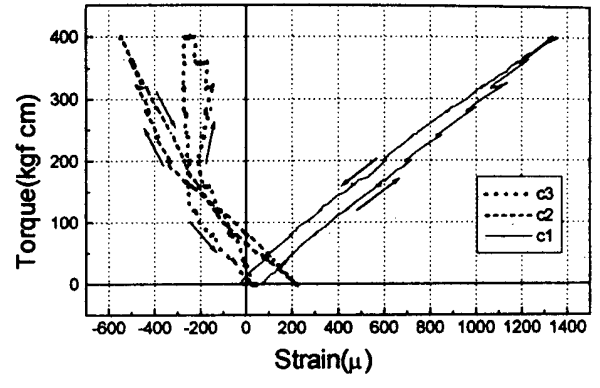

(16a)

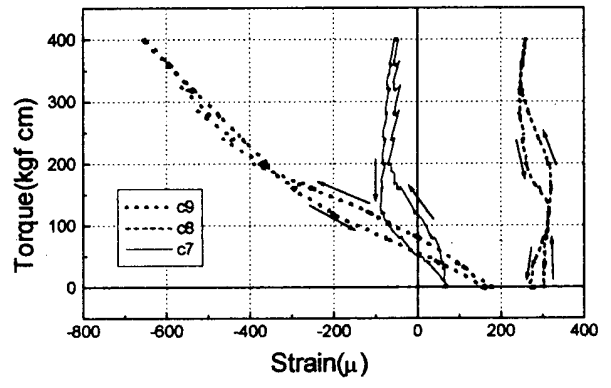

(16b)

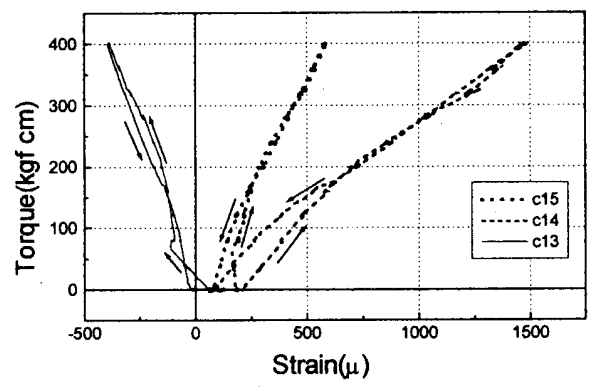

(16c)

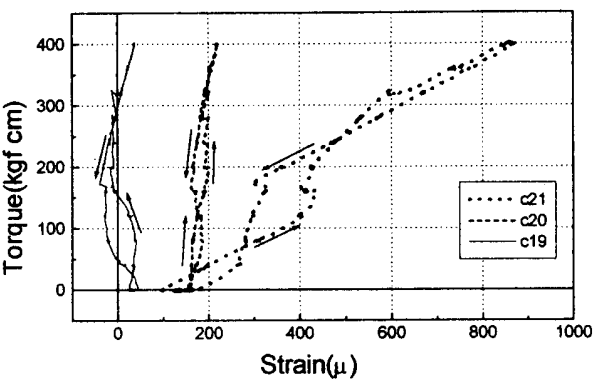

(16d)

図 16 : 㷞りモーメントー歪曲線 ${ }^{19)}$ (MC2：C 種獏)

各图中のc+番号は图 14 に示す表の 歪ゲージの番号に対応する。 


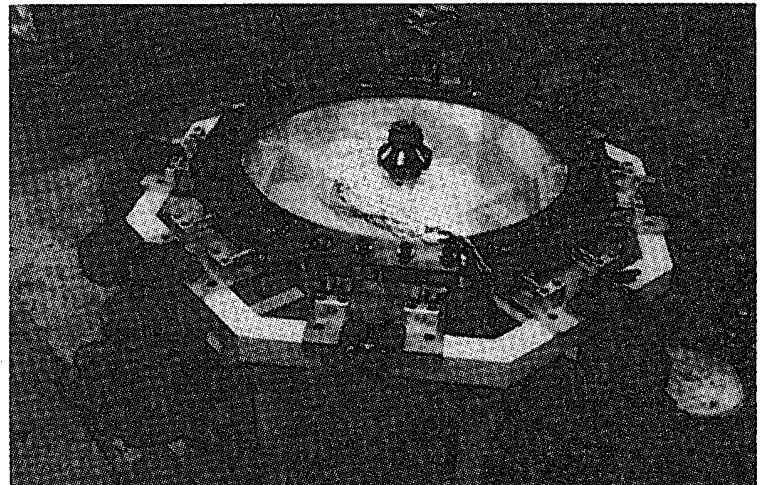

写真 4: ポリエステルフィルム $(\mathrm{ML} 1)$ 、㨭りモーメント $=400 \mathrm{kgf} \cdot \mathrm{cm}$

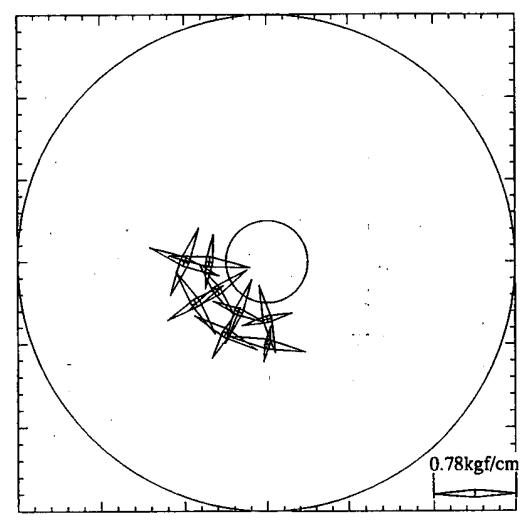

(17a) 初期張力導入直後

（外周の外向き合忍カ $=0.626 \mathrm{Kgf} / \mathrm{cm} 、 1$ チャック $18 \mathrm{Kgf}$ ）

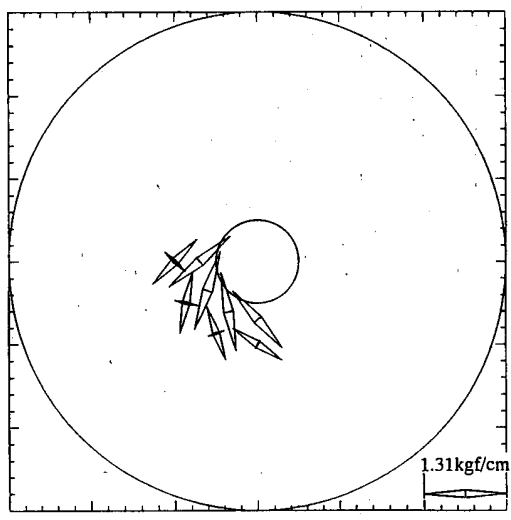

(17b) しわ発生直後 (160Kgf $\cdot \mathrm{cm})$

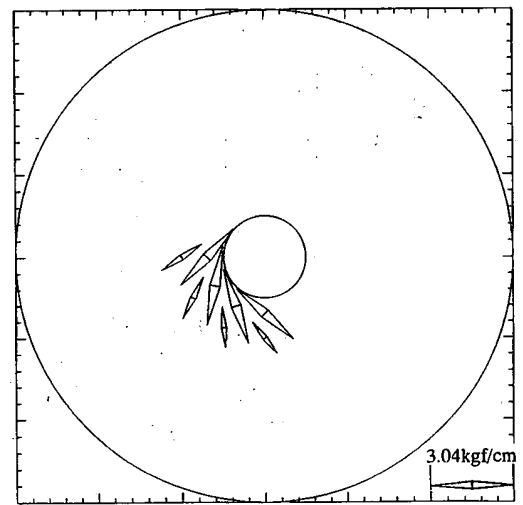

(17c) 㨭りモーメント最大 $(400 \mathrm{Kgf} \cdot \mathrm{cm})$

図 17: 主応力図 (ML1+ML2: ポリエステルフィルム) ${ }^{19\}}$

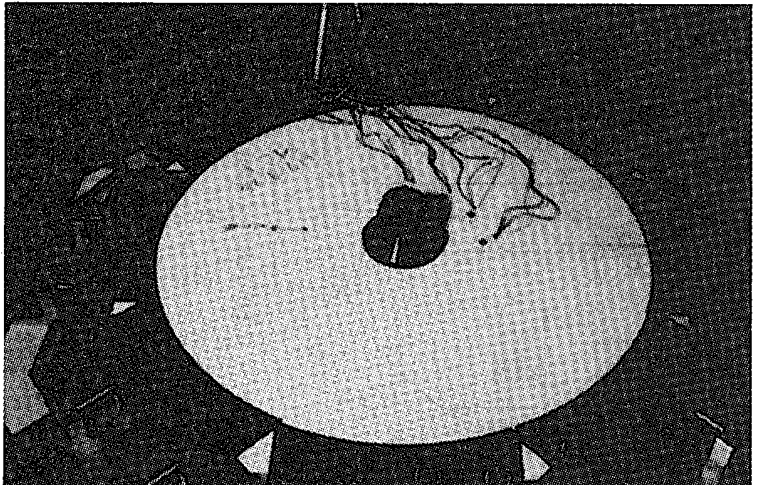

写真 $5: C$ 種莫 $(M C 1) 、$ 㨭りモーメント $=400 \mathrm{kgf} \cdot \mathrm{cm}$

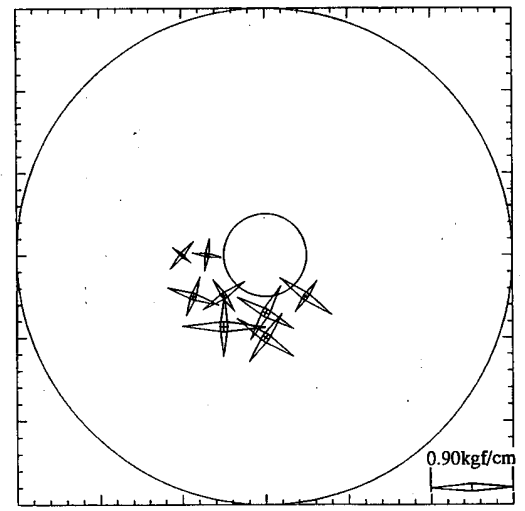

(18a) 初期張力㳯入直後

（外周の外向き合応力 $=0.626 \mathrm{Kgf} / \mathrm{cm} 、 1$ チャック $18 \mathrm{Kgf}$ ）

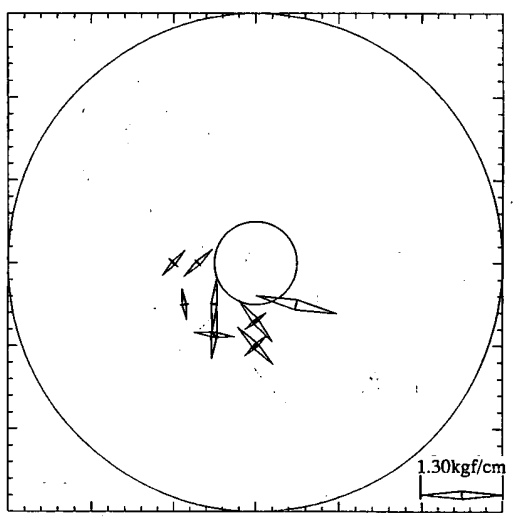

(18b) しわ発生直後 (80Kgf $\cdot \mathrm{cm})$

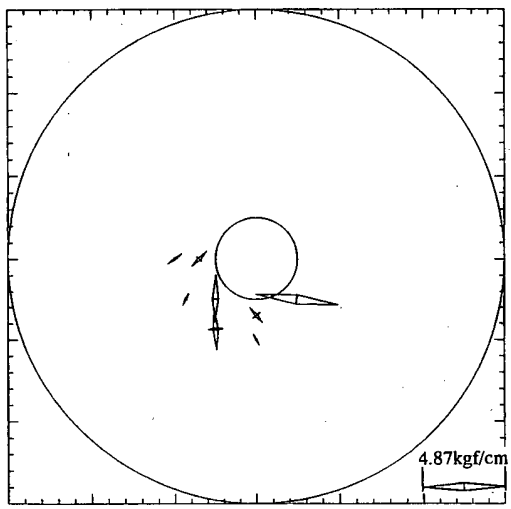

(18c) 提りモーメント最大 $(400 \mathrm{Kgf} \cdot \mathrm{cm})$

図 18: 主応力図 $(M C 1+M C 2: C$ 種膜) 19 
されている。ただし、実際の膜には厚さがあるので片方の面の歪 ゲージの測定值より得られる縁応力は圧縮となることもある。

直交異方性のC 種膜では主応力の向きは緎維方向とほぼ一致し ており、また、図の横軸である縦系方向の応力は横系方向の応力 よりも大きい。更に、繊維方向と一致した中央円盤の接線上の忍 カが特に大きいことがわかる。

写真 4、5 に試験体の様子を示す。ポリエステルフィルムは透明 なのであまりきれいに写らない（写真 4)。C 種膜では緎維の方向 に沿ってしわが発生している様子がわかる（写真5）。また、後に 示す写真 10、11、13 から分かるようにしわの形の特徴はゲージを 貼ったことによってそれほど乱されていない。しわの波状の変形の 中に貼られたグージ付近も、一軸的な応力状態となっていること が分かる。写真を主応力図と比較すると、おおむ敉主応力の向き に沿ってしわが発生しているといえる。

\section{4 各種の膜に発生したしわの形状}

前節までに示した膜以外にもいくつかの膜について実験を行っ ている。ここでは写真のみを示す。写真 $6 \sim 8$ は等方性の膜であり、 それぞれゴム膜、厚めのテフロン膜、薄めのテフロン膜である。 順に薄くなるためしわの本数が多くなっている。残りの写真は直 交異方性の膜である。写真 9 は気球用の膜であり、透明のシート の中に約 $2.5 \mathrm{~mm}$ 間隔の格子状にガラス繊維の系が埋めこまれてい る。写真 10 は $\mathrm{C}$ 種膜であるが、初期張力が前節に示した例よりも 小さい。しわが全体に拡がっている。写真の上下方向が繸系方向で あり、この方向のしわの方が長い。写真 11 は同じ試験体を接写し たものである。写真 12 は厚さ $0.15 \mathrm{~mm}$ の薄い直交異方性のシート である。写真 13 では同じものにゲージを貼って応力測定を行って いる。初期張力は写真 12 の試験体の時よりも大きいため、しわの 本数は写真 12 よりも多くなっている。応力測定の結果は本論文で は省略しているが、最初の C 種膜の結果と良く似たものとなった。

\section{5 結論}

(1) しわの発生した薄い膜の応力測定法を提案した。測定結果から この方法は妥当であると考えられる。

(2) しわ発生領域では中央面の圧縮态力はほぼ零であることが確 認された。従って、それ程厚い膜でなければ、圧縮応力が存在し ないという仮定に基づく張力場理論を適用しても良いといえる。

(3) 直交異方性膜では引張主応力の向きはほぼ䄉維に沿っているこ とが確認された。しわの向きも同様である。これはせん断剛性が ヤング率に比べて相対的に小さいためであると考えられる。建築 では直交異方性の膜が一般的であるので、注意が必要である。

(4)おおむね主応力の向きに沿ってしわは発生する。

(5)C 種膜のように材料非線形性が強い上にクリープを起こすよう な材料であっても、荷重を一定にしておけば、膜の応力状態はそ れ程変化しない。

本実験の結果は有限要素法による分岐解析の結果と比較するこ とにより検証している21)。

\section{謝辞}

本研究の一部は文部省科学研究費補助金（特別研究員奨励費）

によって行った。また、一部の材料試験は太陽工業株式会社空間技
術研究所において同所所員の皆様の協力を得て行った。ここに感 謝致します。

\section{参考文献}

1) W. R. Dean : The Elastic Stability of an Annular Plate, Proc. Roy. Soc. Lond. A.106, pp. 268-284, 1924

2) 井合毅 : 極大エネルギーの定理による弾性問題の解法、日本航空学会 誌、第 10 巻 96 号、pp. 158-180、昭和 18 年 4 月

3) M. Stein, J. H. Hedgepeth : Analysis of Partly Wrinkled Membrane, NASA TN D-813, 1961.7

4) M. M. Mikulas, Jr. : Behavior of a Flat Stretched Membrane Wrinkled by the Rotation of an Attached Hub, NASA TN D-2456, 1964.9

5) E. H. Mansfield : Load transfer via a wrinkled membrane, Proc. Roy. Soc. Lond. A.316, pp. 269-289, 1970

6) K. Moriya, M. Uemura : An Analysis of the Tension Field af ter Wrinkling in Flat Membrane Structures, Proc. IASS Pacific Symposium Part 2 on TENSION STRUCTURES and SPACE FRAMES, Tokyo and Kyoto, pp. 189-198, 1971

7）菊池重昭：張力場理論に関する研究一その 1 、日本建築学会大会学術 諈演梗概集 (東北)、pp. 621-622、1973 年 10 月

8）菊池重昭：張力場理論に関する研究一その 2 、日本建築学会大会学術 講演梗概集 (北陸)、pp. 797-798、1974 年 10 月

9) M. Kawaguchi : The Shallowest Possible Pneumatic Forms, IASS Bulletin, No. 63, 1977

10) M. Hamada and T. Harima : In-plane Torsional Buckling of an Annular Plate, Bulletin of JSME, Vol. 29, No. 250, pp. 1089-1095, 1986

11) D. G. Roddeman, J. Drukker, C. W. J. Oomens and J. D. Janssen : The Wrinkling of Thin Membranes:Part I-Theory, Part IINumerical Analysis, Transactions of the ASME, Vol.54, pp.884892,1987

12) D. G. Roddeman, M. C. van Hout, C. W. J. Oomens, J. D. Janssen and J. Drukker: The Wrinkling of Thin Membranes - Comparison Between Experiments and Theory, ASME AMD(Appl. Mech. Div.), Vol. 84, 267-270, 1987

13）瀬川信哉、三井康司、笹川明：膜材の応カーひずみ曲線からクリーブ を分離した材料定数評価に関する実験的研究、標造工学論文集、Vol 41B、 pp. 259-269、1995

14）塚越勇、森本広明、大野文義 : せん断座屈後の薄膜と鎆板の剛性に 与えるスリットの影響 一銅板耐震壁の㓮性調整に関する研究（その 1)、日本建策学会構造系論文集、No. 467、pp. 131-137、1995

15）宮村倫司、小田害史、半谷裕彦：面内据りを受ける円形張力膜に発 生するしわの実験、膜構造研究論文集'93、第 7 巻、pp. 1-9、1993 年 12 月

16）宮村倫司、半谷裕彦：面内摸りを受ける円形張力膜に発生するしわ の実験および解析、膜粠造研究論文集' $94 、$ 第 8 巻、pp. 1-10、1994 年 12 月

17) T. Miyamura and Y. Hangai : Wrinkling on Isotropic and Orthotropic Elastic Circular Membranes under In-plane Torsion, IASS-Symposium 1995(Milano, Italy),Vol.2, pp.851-858, 1995.6

18）宮村倫司、半谷裕彦：薄い膜構造における近似的な応力测定、日本建 築学会大会学術講演梗概集 B-1 (北海道)、Pp. 731-732、1995 年 8 月

19）宮村倫司、半谷裕彦：面内据りを受ける直交異方性円形張力膜のしわ 発生時の応力測定、膜構造研究論文集' $95 、 p p .37-44$ 、平成 7 年 12 月

20）宮村倫司、半谷裕彦：回転対称膜構造物に発生するしわの有限要素法 による解析、日本建筑学会構造系論文集、第481 号、pp. 63-70、1996 年 3 月

21）宮村倫司、半谷裕彦：面内据りを受ける円形張力膜のしわの実検と解 析の比較、日本建築学会大会学術講演梗概集 B1（近畿）、pp. 889-890、 1996 年 9 月

22）宫村倫司：張力膜におけるしわの分岐解析および実験、東京大学博士 論文、平成 7 年 12 月

23）日本膜構造協会試験法標隻：膜材料面内女ん断用性試験法（MSAJ/M 01-1993)、日本膜構造協会、1993 


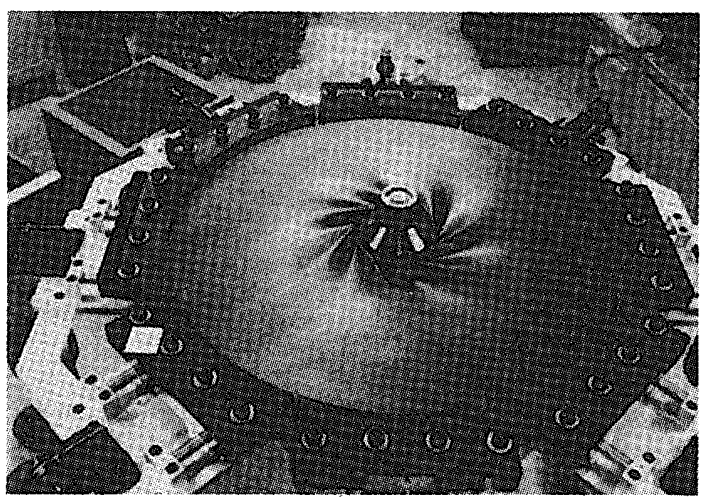

写真 6: ゴム（厚さ $=1.0 \mathrm{~mm} 、$ 等方性） 151

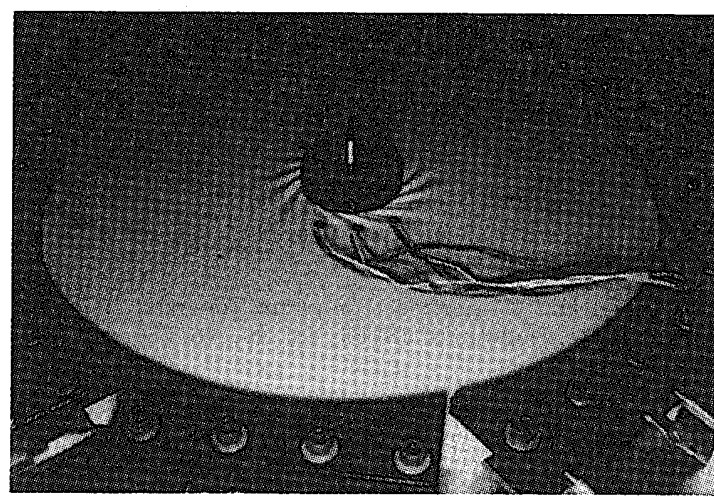

写真 7: テフロンフィルム（厚さ $=0.20 \mathrm{~mm}$ 、等方性）

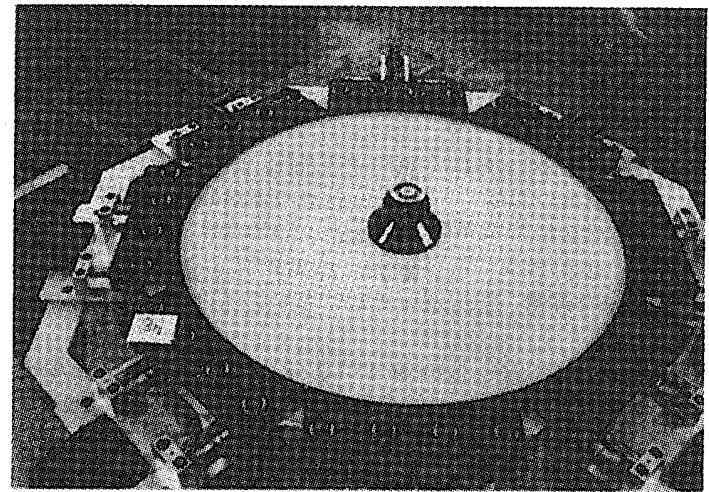

写真 8: テフロンフィルム（厚さ $=0.10 \mathrm{~mm}$ 、等方性） ${ }^{151}$

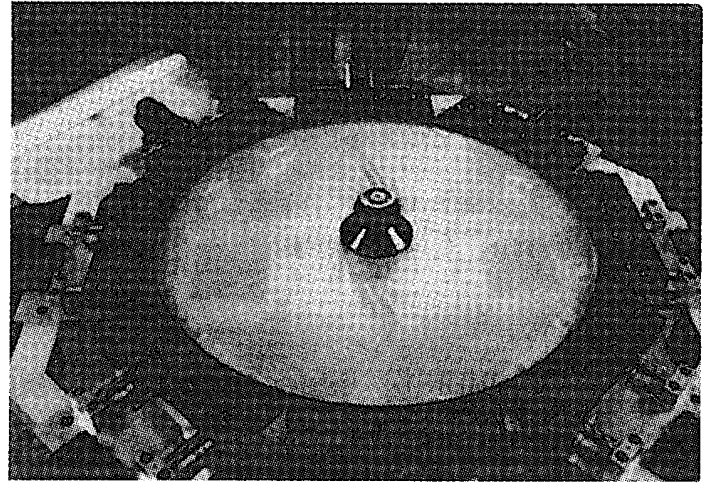

写真 9: 気球用の膜（厚さ $=0.10 \mathrm{~mm}$ 、直交異方性） ${ }^{151}$

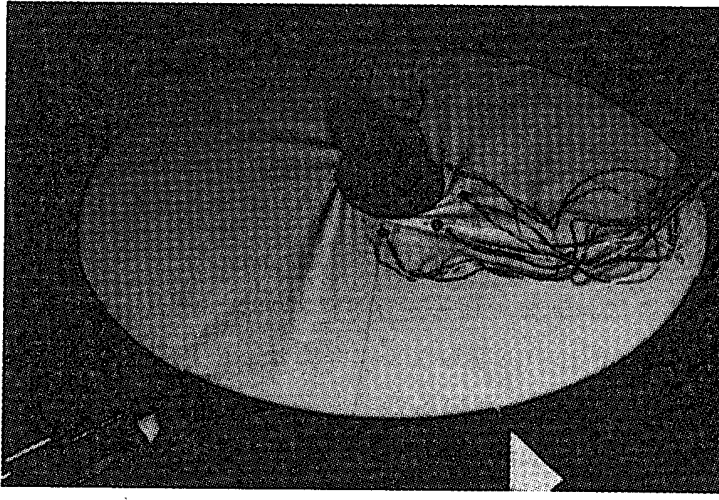

㝍真 10: C種膜（厚さ $=0.5 \mathrm{~mm}$ 、直交異方性、

MC1、MC2 と同し膜、初期張かはチャックあたり 10Kgf)

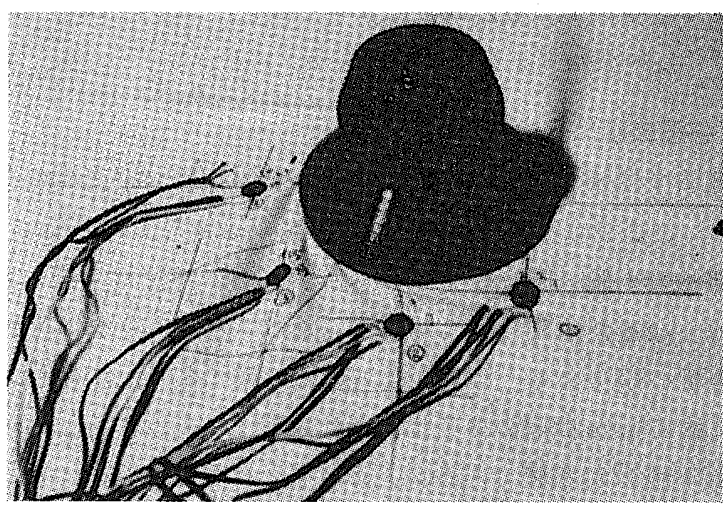

写真 11: C種膜（写真 10の接写）

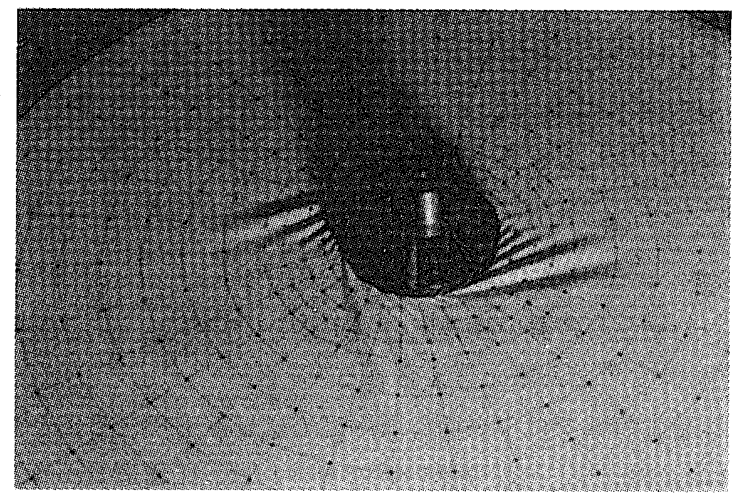

写真 12: コーティングされた薄い膜（厚さ $=0.15 \mathrm{~mm}$ 、 直交異方性、初期張力はチャックあたり 10Kgf） ${ }^{16 !}$

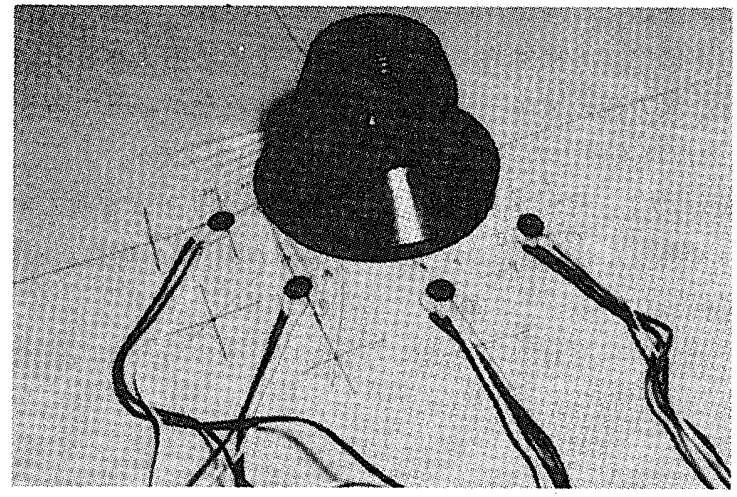

写真 13: コーティングされた薄い膜（写基 12 と同じ膜にグージ を貼って応力を測定中、初期張カはチャックあたり 18Kgf）

（1996年10月 9 日原稿受理，1996年12月12日採用決定） 